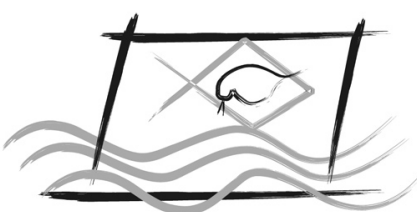

ECOTOX - BRASIL

\title{
Detection of metals by differential pulse anodic stripping voltammetry (DPASV) in pollen collected from a fragment of the atlantic forest in Piracicaba/SP
}

\author{
T.A. Da Silveira ${ }^{1}$; D.F.D. Araujo'; L.C. MarchinI ${ }^{1}$; A.C.C.C. Moreti ${ }^{2} \&$ R.A. Olinda ${ }^{3}$ \\ ${ }^{1}$ Escola Superior de Agricultura “Luiz de Queiroz”, Universidade de São Paulo, ESALQ/USP. Departamento de Entomologia e \\ Acarologia, Laboratório de Insetos Úteis. \\ ${ }^{2}$ Instituto de Zootecnia, Secretaria de Agricultura e Abastecimento \\ ${ }^{3}$ Universidade Estadual da Paraíba, Centro de Ciências e Tecnologia - CCT/UEPB
}

(Received September 14, 2012; Accept July 26, 2013)

\begin{abstract}
Detection techniques of trace elements have high costs for routine analysis while differential pulse anodic stripping voltammetry (DPASV) has low operational costs and few structural requirements. This technique was considered a good alternative for pollen analysis. In the analyses, Zinc, Copper and Lead showed concentrations higher than the threshold established for human daily intake of food; however, Cadmium concentrations did not exceed the limits. The high concentrations found may be explained by the geographical locality of the apiary, which is located near the main road to access the city and a water and sewage treatment plant. In addition, other anthropogenic processes, namely agricultural, industrial and residential activities may have influenced. The technique of voltammetry can be considered a good alternative for pollen routine analysis, providing accuracy at lower costs. The study provides information about the contamination of the matrix of bee pollen.
\end{abstract}

Keywords: bee, biomonitoring, detection limits, trace elements.

\section{INTRODUCTION}

Interest in consumption of safe products has been increasing in the past years worldwide. People have become more concerned about the health conditions and well-being, seeking food with no or minimal concentrations of chemical additives (preservatives, acidulants, among others).

In the group of natural foods, safety plays a key role in their marketing and acceptance in the market, receiving a great deal of attention from inspecting agencies. Over the years, bee products (pollen, royal jelly, bee venom) as well as honey have gained a significant market share in the sector of natural products.

According to Ordinance No. 3 of 2001 of the Brazilian Ministry of Agriculture and Supply (Brasil 2001), pollen is defined as the result of agglutination of flower pollen, made by worker bees through nectar and saliva substances, collected at the hive entrance. Although pollen has well-defined rules as to their physical-chemical compositions, the presence of trace metals (heavy metals) in pollen is another factor has greatly concerned inspecting agencies. Produced in areas near urban environments to facilitate the activity, pollen may be subject to contamination sources (roads, farms, buildings, etc.) that go unnoticed by beekeepers (Pohl et al., 2009).

Bees move around an approximately $10 \mathrm{~km}$ radius to search for food source quality, and during those trips, they come into contact with many contamination sources. Heavy metals in the atmosphere can be deposited on flowers, water, air, soil and hairs of bee body, and thus, be transported the hives along with pollen grains (Porrini et al., 2003).

It is known that trace metals such as sodium, potassium, calcium, iron, zinc and copper can be considered essential for

*Corresponding author: Talita Antonia da Silveira; e-mail: tali_aband@hotmail.com 
the biological metabolism of living organisms. Other metals such as lead, cadmium, mercury, aluminum are classified as micro-contaminants of the environment, toxic or non-essential to living organisms and at high concentrations, can be even lethal (Oga et al., 2008)

Detection techniques of trace metals generally have high costs to be used in routine analysis (Tonietto et al., 2012). However, differential pulse anodic stripping voltammetry (DPASV), has low operating costs and few structural requirements, besides having a scanning of "ppt" (parts per trillion) (Rodrigues 1998).

Therefore, this study aimed to apply the voltammetry technique as an alternative to measure trace metals in pollen for in routine analysis, providing accuracy at lower costs over other methods. The present study aimed to also provide information about the contamination of the matrix of pollen.

\section{MATERIALS AND METHODS}

The experiment was conducted in a fragment of the Atlantic forest located at the Department of Entomology and Acarology at College of Agriculture "Luiz de Queiroz", campus ESALQ/ USP, in the municipality of Piracicaba, in São Paulo state, Brazil. The site was chosen for having a 7-km radius and its proximity to agricultural, industrial and urban areas, a sewage and water treatment plant of the Piracicamirim River and main road to access the city. Thus, the bee products generated could be exposed to contamination sources.

In the beehive, we kept five colonies of Africanized honey bees (Apis mellifera $\mathrm{L}$ ) Langstroth-type boxes. The pollen was sampled during one year in each of the four seasons (summer, autumn, winter and spring) with two collections, one at the beginning and another at the end of the season ( $\mathrm{A}$ and $\mathrm{B}$ winter; $\mathrm{C}$ and $\mathrm{D}$ spring; $\mathrm{E}$ and $\mathrm{F}$ summer and $\mathrm{G}$ and $\mathrm{H}$ autumn). Were installed a front-type trap to obtain at least $50 \mathrm{~g}$ of pollen per beehive per season. The beehives were kept under conditions to favor pollen collection, standardization of the bee population and percentage of pollen retained in the traps.

\section{Samples}

Pollen loads in the traps were removed every collection day, cleaned by grooming, weighed and stored in $250 \mathrm{~mL}$ plastic bottles, sealed and stored in a freezer at $-26^{\circ} \mathrm{C}$ until analysis. In all analyses, we used samples in a fresh base.

\section{Analysis of minerals and trace metals: $\mathrm{Zn}, \mathrm{Cu}, \mathrm{Cd}$ and $\mathrm{Pb}$}

\section{Sample digestion}

We weighed approximately $0.5 \mathrm{~g}$ of the pollen sample in a $250 \mathrm{~mL}$ flat-bottomed flask and $5 \mathrm{~mL}$ of concentrated nitric acid (HNO3, Sigma-Aldrich $\left.{ }^{\circledR}\right)$ was added, with a reflux condenser connected to the flask mouth. The flaks were kept on a plate heated at $120^{\circ} \mathrm{C}$ for the mixture remain in reflux
30 minutes. Afterwards, the material was cooled to room temperature, then $2 \mathrm{~mL}$ of nitric acid $\left(\mathrm{HNO}_{3}\right)$ and $3 \mathrm{~mL}$ of concentrated perchloric acid $\left(\mathrm{HClO}_{4}\right.$, Sigma-Aldrich $\left.\AA\right)$ were added to submit to reflux for 60 minutes once again. Thereafter, the condenser was removed for the elimination of acids and concentration of the sample. The concentrate was diluted in ultrapure water (Mohm $18.2 \mathrm{~cm}$ ) in a $25 \mathrm{~mL}$ volumetric flask. The blank solution containing only acid used in the digestion underwent a similar procedure (Pereira, 2010).

\section{Voltammetry}

The trace metals $(\mathrm{Cu}, \mathrm{Pb}, \mathrm{Cd}$ and $\mathrm{Zn})$ were quantified in a

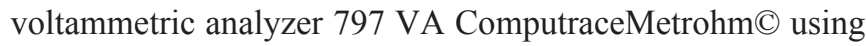
electrochemical measures. The differential pulse voltammetry is an electroanalytical technique based on phenomena occurring at the interface between the electrode surface and the thin layer of solution adjacent to the surface. The method is considered dynamic, because the electrochemical cell is operated in the presence of electrical current ( $\mathrm{i}>0$ ), which, in turn, is measured by the controlled application of potential (Skoog et al., 1992) Therefore, information on the analyte (aqueous solution containing ions) is obtained by measuring the magnitude of the electrical current that appears in the working electrode by applying a voltage between a working and an auxiliary electrode. The registration of the current potential may be related to the amount of analyte found in the electrode interface (Montenegro et al., 1991).

The equipment is coupled to a computer with the $797 \mathrm{VA}$ Computrace software version 1.3.1 Metrohm ${ }^{\circledR}$ to record and read the measures. To determine zinc $\left(\mathrm{mg} \mathrm{Kg}^{-1}\right)$, cadmium $\left(\mu \mathrm{gg}^{-1}\right)$, lead ( $\mathrm{mg} \mathrm{Kg}^{-1}$ ) and copper $\left(\mathrm{mg} \mathrm{Kg}^{-1}\right)$, we used the technique of differential pulse anodic stripping voltammetry (DPASV) (Taddia et al., 2004).

The standardaddition method was used for the determination of the metals. The reagents and standard solutions used were from Sigma-Aldrich ${ }^{\circledR}$ and QuimLabSpecSol ${ }^{\circledR}$. The solutions were prepared with ultrapure water (Mohm 18.2 $\mathrm{cm}$ ) and all flasks were kept in $\mathrm{HNO}_{3}$ at $10 \%$ for 24 hours for decontamination. Prior to use, all material was rinsed with ultrapure water. The parameters and conditions of the analyses are shown in Table 1.

\section{Statistical Analyses}

The data for the $\mathrm{Zn}, \mathrm{Cu}, \mathrm{Pb}$ and $\mathrm{Cd}$ were analyzed by analysis of variance (ANOVA). We checked the ANOVA assumptions using the optimal transformation family of BoxCox (Box et. al., 1964) and the Hartley (1950) test was used to verify the homogeneity variances. The experimental design was completely randomized and the treatments comprised different pollen types. Once the ANOVA assumptions were verified, we applied the $F$ test $(p<0.05)$ to investigate possible differences between the levels of the Pollen factor. We proceeded with the analysis by performing test of means comparisons, two by two, in the Tukey test $(p<0.05)$. In order 
Table 1 - Parameters and conditions used in the polarographic cell for the determination of $\mathrm{Zn}^{2+}, \mathrm{Cd}^{2+}, \mathrm{Pb}^{2+}$ and $\mathrm{Cu}^{2+}$ by DPASV

\begin{tabular}{|c|c|c|}
\hline Voltametric Parameters & Unity & $\mathrm{Zn}^{2+}, \mathrm{Cd}^{2+}, \mathrm{Pb}^{2+}$ and $\mathrm{Cu}^{2+}$ \\
\hline Dilluted sample volume & $\mathrm{mL}$ & 1 \\
\hline Ultrapure water volume & $\mathrm{mL}$ & 10 \\
\hline \multicolumn{3}{|l|}{ Electrolytes } \\
\hline $\begin{array}{l}\mathrm{KCl} 1.5 \mathrm{~mol} \mathrm{~L}-1 \text { and Acetate } \\
\text { of Sodium } 0.5 \mathrm{~mol} \mathrm{~L}-1\end{array}$ & $\mathrm{~mL}$ & 2 \\
\hline Working electrode & & HMDE \\
\hline No. of drops & & 4 \\
\hline No. of additions & & 2 \\
\hline No. of replications & & 3 \\
\hline Reference electrode & & $\mathrm{Ag} / \mathrm{AgCl}\left(\mathrm{KCl} 3 \mathrm{~mol} \mathrm{~L}^{-1}\right)$ \\
\hline Auxiliar electrode & & Platinum \\
\hline Shake speed & 2000 & RPM \\
\hline Purge time ( $\mathrm{N}_{2}$ ultrapure) & $\mathrm{s}$ & 300 \\
\hline Additional purge time & s & 10 \\
\hline Deposition potential & $\mathrm{V}$ & -1.15 \\
\hline Deposition time & s & 90 \\
\hline Equilibrium time & $\mathrm{s}$ & 10 \\
\hline Pulse amplitude & $\mathrm{mV}$ & 0.05 \\
\hline Initial potential & $\mathrm{V}$ & -1.15 \\
\hline $\mathrm{Zn}^{2+}$ & $\mathrm{V}$ & -0.98 \\
\hline $\mathrm{Cd}^{2+}$ & V & -0.61 \\
\hline $\mathrm{Pb}^{2+}$ & V & -0.38 \\
\hline $\mathrm{Cu}^{2+}$ & $\mathrm{V}$ & -0.16 \\
\hline
\end{tabular}

to verify if the seasons can be classified using the concentrations of heavy metals ( $\mathrm{Zn}, \mathrm{Cu}, \mathrm{Pb}$ and $\mathrm{Cd}$ ), we used the canonical discriminant analysis. Data were analyzed using the computer program (SAS/Stat 9.1.3 Service Pack 2, 2003).

\section{RESULTS AND DISCUSSION}

The analysis of $\mathrm{Zn}, \mathrm{Cu}, \mathrm{Pb}$ and $\mathrm{Cd}$ showed different profiles in each season. Thus, a number of variables such as climate, season and botanical origin must be considered when using bees or bee products to monitor trace metals in the environment (Bogdanov 2006; Embrapa Clima Temperado 2008). The mineral composition depends not only on the botanical origin, but on the growth conditions such as soil type and geographical origin (Serra-Bonvehí et al., 1997).

The average zinc concentrations found in pollen collected in the four seasons showed no significant differences in the variance analysis. In this study, the maximum $\mathrm{Zn}$ content was $259.52 \mathrm{mg} \mathrm{Kg}^{-1}$ and minimum $124.58 \mathrm{mg} \mathrm{Kg}^{-1}$, which are very high compared to the recommended daily intake for adults of about $15 \mathrm{mg} \mathrm{Kg}^{-1}$ (Franco 1999). Serra-Bonvehí et al. (1997) found different results for pollens collected in Spain where the $\mathrm{Zn}$ contents did not exceed a maximum of $81.1 \mathrm{mg} \mathrm{Kg}^{-1}$ and minimum of $18.8 \mathrm{mg} \mathrm{Kg}^{-1}$, which are similar to results for other honey products in that country. In Australia, Somerville \& Nikol (2002) found Zn contents similar those in this study, which may be linked to the dominant Eucalyptus species in Brazil that has great $\mathrm{Zn}$ contents. Morgano et .al., (2012) found $\mathrm{Zn}$ contents that ranged from $41.4-65.3 \mathrm{mg} \mathrm{Kg}^{-1}$, and only one sample presented a lower content $\left(5.1 \mathrm{mg} \mathrm{Kg}^{-1}\right)$.

Intoxication cases may occur either through ingestion of contaminated food and beverages, by exposure to dust and fumes with high zinc concentrations or skin contact with zinc salts. Zinc becomes dangerous when combined with other metals such as cadmium and lead (Rocha et al., 1985) (Table 2).

The results show that only Cadmium levels in spring exceeded the limit recommended for daily intake (Table 2). FAO (2005) established a provisionally tolerable weekly intake of $7 \mu \mathrm{g} \mathrm{Kg}^{-1}$ of body mass index. Considering the threshold for a $70 \mathrm{Kg}$ person, the cadmium concentration found did not exceed $490 \mu \mathrm{g} \mathrm{Kg}^{-1}$. In the other seasons, cadmium showed concentrations below tolerable limits. Morgano et al., (2010) apud Leita, reported high Cd contents (near $50 \mathrm{~m}$ ) in urban centers with high traffic intensity that surpassed the concentration of $2.1 \mathrm{mg} \mathrm{Kg}^{-1}$ in the pollen collected by bees in this region. Morgado et al., (2010) found Cd in $79 \%$ of the samples, which was greater than in this study $(<0.001-0.233$ $\left.\mathrm{mg} \mathrm{Kg}{ }^{-1}\right)$ compared to samples collected in Italy $(<0.015-0.090$ $\mathrm{mg} \mathrm{Kg}{ }^{-1}$, wet weight), in the United Kingdom $(<0.07-0.13 \mathrm{mg}$ $\mathrm{Kg}^{-1}$ ) and Spain (0.07-0.10 $\mathrm{mg} \mathrm{Kg}^{-1}$ ) (Maff 1995).

Cadmium is listed in 8th place as hazardous substances (Salgado 2008) Cadmium in the environment is absorbed and retained by aquatic and terrestrial plants, by animals that feed on these plants and ultimately by humans, as the last link of the food chain (Ramos 2005).

Lead concentrations exceeded the tolerable limits in all samples (Table 2). The weekly tolerable intake is $25 \mu \mathrm{g} \mathrm{Kg}^{-1}$ of body mass (WHO 2005), which is equivalent to $3.57 \mu \mathrm{g} \mathrm{Kg}^{-1}$ of body weight per day. It is worth noting that decree No. 685 of August 27, 1998, of the National Agency of Health Vigilance

Table 2 - Mean values ${ }^{(1)}$ of trace elements zinc $\left(\mathrm{mg} \mathrm{Kg}^{-1}\right)$, copper $\left(\mathrm{mg} \mathrm{Kg}^{-1}\right)$, lead $\left(\mathrm{mg} \mathrm{Kg}^{-1}\right)$ and cadmium $\left(\mu \mathrm{g} \mathrm{Kg}^{-1}\right)$ in pollen loads collected in hives of Apis mellifera in the municipality of Piracicaba, São Paulo state, Brazil, in four seasons between 2010-2011.

\begin{tabular}{lcccc}
\hline Season & \multicolumn{4}{c}{ Metals } \\
\hline Winter & $193.63 \pm 21.42 \mathrm{~A}$ & $115.80 \pm 50.29 \mathrm{BC}$ & $29.620 \pm 2.38 \mathrm{~A}$ & $85.66 \pm 21.95 \mathrm{~A}$ \\
Winter & $259.52 \pm 57.93 \mathrm{~A}$ & $231.04 \pm 55.54 \mathrm{~B}$ & $27.320 \pm 3.85 \mathrm{~A}$ & $65.16 \pm 7.58 \mathrm{AB}$ \\
Spring & $231.04 \pm 50.81 \mathrm{~A}$ & $565.54 \pm 85.34 \mathrm{~A}$ & $32.020 \pm 6.04 \mathrm{~A}$ & $53.36 \pm 6.87 \mathrm{AB}$ \\
Spring & $212.22 \pm 34.39 \mathrm{~A}$ & $245.08 \pm 17.18 \mathrm{~B}$ & $25.340 \pm 1.89 \mathrm{~A}$ & $44.98 \pm 4.50 \mathrm{~B}$ \\
Summer & $223.30 \pm 34.86 \mathrm{~A}$ & $195.00 \pm 21.45 \mathrm{~B}$ & $25.440 \pm 3.90 \mathrm{~A}$ & $37.32 \pm 4.72 \mathrm{~B}$ \\
Summer & $229.38 \pm 50.29 \mathrm{~A}$ & $159.22 \pm 41.20 \mathrm{BC}$ & $26.200 \pm 3.82 \mathrm{~A}$ & $55.52 \pm 7.05 \mathrm{AB}$ \\
Autumn & $187.72 \pm 14.46 \mathrm{~A}$ & $199.90 \pm 35.74 \mathrm{~B}$ & $26.400 \pm 4.60 \mathrm{~A}$ & $38.66 \pm 6.38 \mathrm{~B}$ \\
Autumn & $124.58 \pm 14.58 \mathrm{AB}$ & $112.60 \pm 9.56 \mathrm{BC}$ & $23.320 \pm 3.84 \mathrm{~A}$ & $36.70 \pm 5.67 \mathrm{~B}$ \\
\hline
\end{tabular}

Means followed by the same letters do not differ statistically $(\mathrm{p}<0.05)$ in the Tukey test. ${ }^{(1)}$ 
(Brazil), established lead threshold for several foodstuffs, however, there is no reference to levels in bee products. Thus, lead concentration in soils varies from region to region, so in regions close to roads with heavy traffic and industries, lead levels are much higher than in isolated areas (Larini 1993). The high level of lead in spring may be explained by a higher occurrence of wind in this season, which would transport the metal over long distances.

Lead showed a high concentration in the first sampling of spring when cadmium concentrations were also high. Morgano et al., (2010) conducted studies in São Paulo State, Brazil, and found pollen with higher $\mathrm{Cd}$ and $\mathrm{Pb}$ contents in the spring in the month of October, and $\mathrm{Pb}$ was present in 63\% of the samples. Similarly to results found for Cd contents, São Paulo State showed the highest $\mathrm{Pb}$ contents $(<0.01-0.44$ $\left.\mathrm{mg} \mathrm{Kg}{ }^{-1}\right)$. The same condition was reported in studies carried out on pollens in Europe $\left(<0.02-0.329 \mathrm{mg} \mathrm{Kg}^{-1}\right.$ in Italy; $0.3-$ $1.5 \mathrm{mg} \mathrm{Kg}^{-1}$, in the United Kingdom and 0.1-0.14 mg Kg Spain) (Maff 1995).

The study of metal content of Swiss honeys and honeydew in contaminated areas (large cities, roads, incineration areas) showed a positive relationship between $\mathrm{Pb}$ and $\mathrm{Cd}$ in honey and their concentrations in the environment. The authors also noted that while $\mathrm{Pb}$ concentration increases in double, $\mathrm{Cd}$ concentrations did not change. This is because cadmium reaches the soil and contamination occurs in the soil, while $\mathrm{Pb}$ contamination occurs in the air. The cited authors noted that metal concentrations in honey are directly related to botanical resources, considering, therefore, honey as a good indicator of $\mathrm{Pb}$ concentrations in various regions of a contaminated area within a radius of $2 \mathrm{Km}$ (Bogdanov 1986).

The daily intake threshold for copper established by the Brazilian legislation for adults is $900 \mu \mathrm{g}$ (Brasil 2005). In healthy adults and not occupationally exposed to copper, the main pathway for the copper ingestion is oral. Chronic intoxication in humans is uncommon and is usually associated with cases of accidental ingestion (Lima et al., 2001).

Like other metals, copper is dispersed in the environment by wind, rain and water streams. Water is an important source of copper exposure, especially in households where pipes are made of copper. Copper concentration in food generally varies from 0.2 to $44 \mu \mathrm{g} \mathrm{g}^{-1}$ of dry weight (Lima et al., 2001).

Copper showed an average of $85.6 \mathrm{mg} \mathrm{Kg}^{-1}$ in the first sampling in winter and $36.7 \mathrm{mg} \mathrm{Kg}^{-1}$ in the second sampling in fall. Morgano et al., (2012) found concentrations between 10$18 \mathrm{mg} \mathrm{Kg}^{-1}$ for the São Paulo State. This high contamination level can be associated to the proximity of the area with the water and sewage treatment plant, since copper sulphate is used to inhibit algae growth in tanks of the treatment plant (Ramos 2005).

Kalbande et al., (2008) evaluated pollen grains from different species under different conditions of exposition to the environment and observed that there is a significant difference between the fresh pollen and pollen from urban centers in terms of metal contents in the pollen. The concentrations of
$\mathrm{Pb}, \mathrm{Zn}$ and $\mathrm{Cd}$ reached $200 \%$ greater in urban pollen compared to fresh pollen, depending on the species.

Will hardly reported cases of intoxication with ingestion of pollen once the maximum daily consumption of this product in humans is $25 \mathrm{~g}$ that hardly reach the maximum limit of daily ingestion of metals studied $(\mathrm{Zn}, \mathrm{Cd}, \mathrm{Pb}$ and $\mathrm{Cu})$.

\section{Canonical Discriminant Analysis}

In the set of samples evaluated, including heavy metals concentration ( $\mathrm{Zn}, \mathrm{Cd}, \mathrm{Pb}$ and $\mathrm{Cu})$ and the seasons when the samplings were made, we attempted to determine whether the seasons would discriminate among one another.

Evaluating the sample dispersion and the ellipses formation in some groups (Fig. 1), there is a separation on one of the canonical axes which represents the first sampling in spring that was the only sampling to distant from the others. In order to verify if the seasons can be classified by concentrations of heavy metals $(\mathrm{Zn}, \mathrm{Cu}, \mathrm{Pb}$ and $\mathrm{Cd})$, we used a canonical discriminant analysis based on Mahalanobis distance, taking into account the correlations between the variables with which different patterns can be identified and analyzed. Therefore, it was possible to determine similarity between the samples of winter, summer, autumn and spring 2 , considering correlations in the data set.

These results for the metals analyzed in pollen corroborate data found by (Bromenshenk et al., 1984; Kovacheva et al., 2000; Lozak et al., 2002; Atrouse et al., 2004; Rissato et al., 2006 \& Sobukola et al., 2008), where accidental contamination may occur due to environmental pollution caused by pesticides and fertilizers in water and soil, or air caused by heavy traffic of vehicles emitting pollutants.

Thus, concentrations of trace metals in honey bee products reflect the profile of metal of a given region, which may be a useful tool to assess contamination levels of the environment. Therefore, determining trace metals concentrations is of great importance especially for quality control of honey bee products, since higher levels of metals are undesirable because of their toxicity (Bogdanov et al. 2003).

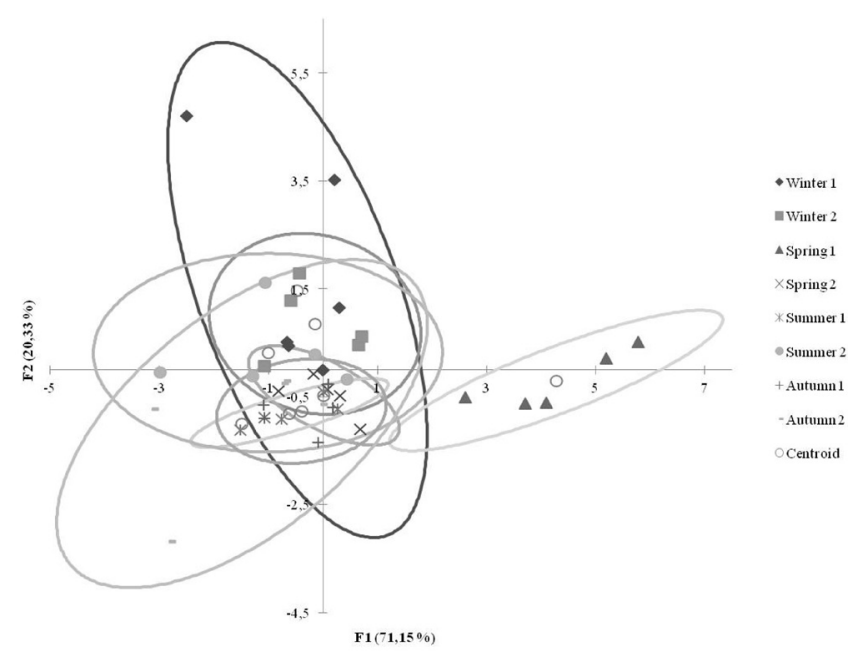

Figure 1 - Discriminant functions of seasons and metal concentrations. 
The technique of voltammetry to measure trace elements in pollen can be considered a good alternative for routine analysis, providing accuracy at lower costs. The results of analyses show that the metals zinc, copper and lead have concentrations higher than thresholds established for daily intake of food. The discussions were based on daily consumption of food once again that there is no data in the literature with respect to pollen as environmental indicator. Cadmium concentrations did not exceed thresholds for human consumption, however, a high concentration was found in pollen. The concentrations of trace metals found could be associated with the geographic locality of the apiary and influenced by the proximity to various sources of pollution such as vehicle traffic, water and sewage treatment plant, agricultural, industrial and residential areas.

\section{ACKNOWLEDGMENT}

We wish to thank FAPESP and CAPES for the financial support to the research project.

\section{REFERENCES}

ATROUSE, O. M.; ORAN, S.A. \& AL-ABBADI, S.Y. 2004. Chemical analysis and identification of pollen grains from different Jordanian honey samples. Int. J. Food Sci. Technol 39:413417. http://dx.doi.org/10.1111/j.1365-2621.2004.00798.x

BOGDANOV, S. 2006.Contaminants of bee products. Apidologie, 37:1-18. http://dx.doi.org/10.1051/apido:2005043

BOGDANOV, S.; IMDORF, A; CHARRIERE, J.; FLURI, P. \& KILCHENMANN, V. 2003. The contaminants of the bee colony. Bern: Swiss Bee Research Centre.12p.

BOGDANOV, S.; ZIMMERLI, B. \& ERARD, M. 1986. Heavy metals in honey. Mitt. Gebiete Lebensm. Hyg., 77153-158.

BOX, G.E.P. \& COX, D.R. 1964. An analysis of transformations (with discussion). J. R. Stat. Soc. Ser. B Stat. Methodol 26:211252.

BRASIL. 2005. Ministério da Saúde. Resolução da Diretoria Colegiada (RDC) n 269, de 22 de outubro de 2005. Regulamento Técnico Sobre a Ingestão Diária Recomendada (IDR) de Proteína, Vitaminas e Minerais. Diário Oficial da União, Brasília, DF, 22 set. 2005.

BRASIL. Instrução Normativa n.3 de 2001. Regulamento técnico para fixação de identidade e qualidade de pólen apícola. Ministério de Agricultura, Pecuária e do abastecimento. Disponível em $<\mathrm{http}$ // www.apacame.org.br/mensagemdoce/52/polen.htm. Acesso em: 16 jun. 2010.

BROMENSHENK, J. J. ; CARLSON, S. R.; SIMPSON, J.C. \& THOMAS, J.M. 1984. Pollution Monitoring of puget sound with honey bees. Science, 227:632-634. http://dx.doi.org/10.1126/ science.227.4687.632

EMBRAPA CLIMA TEMPERADO. 2008. Abelhas melíferas: bioindicadores de qualidade ambiental e de sustentabilidade da agricultura familiar de base ecológica. Pelotas, $38 \mathrm{p}$.

FAO. Food and Agricultural Organization. 2005. Of The United Nations; World Health Organization - FAO / WHO. Summary and conclusions of the sixty- fourth meeting of the Joint FAO/ WHO Expert Committee on Food Additives (JECFA). Disponível em $<$ http//www.who.int/ipcs/food/jecfa/summary_report_64 final.pdf $>$.Acesso em: 16 ago. 2010.

FRANCO, G. 1999. Tabela de composição química dos alimentos. 9. ed. São Paulo: Atheneu, 307p.
HARTLEY, H.O. 1950. The use of range in analysis of variance. Biometrika, 37: 271-280. http://dx.doi.org/10.1093/ biomet/37.3-4.27.

KALBANDE, D.M.; DHADSE, S.N.; CHAUDHARI, P. R. \& WATE, S.R. 2008. Biomonitoring of heavy metals by pollen in urban environment. Environ. Monit. Assess. 138:233-238. http:// dx.doi.org/10.1007/s10661-007-9793-0

KOVACHEVA, P.; DJINGOVA, R. \& KULEFF, I. 2000. On the representative sampling of plants for multielement analysis. Phytol. Balcan ,6:91-92.

LARINI, L. 1993. Toxicologia dos praguicidas. 3.ed. São Paulo: Manole. 120p.

LIMA, I. V. \& PEDROZO, M. F. M. 2001. Ecotoxicologia do cobre e seus compostos. Salvador: Centro de Recursos Ambientais (CRA), 128p. 2v. (Séries Caderno de Referências Ambientais). Disponível em: $<\mathrm{http} / /$ web.cena.usp.br/apostilas $>$. Acesso em: 15 dez. 2010.

LOZAK, A.; SOLTYK, K.; OSTAPCZUK, P. \& FIJALEK, Z. 2002. Determination of selected trace elements in herbs and their infusions. Sci. Total Environ., 289: 33-40. http://dx.doi. org/10.1016/S0048-9697(01)01015-4

MAFF U.K. Analysis of bee products for heavy metals; FoodnSurveillance Information Sheet 53; 1995; http://archive. food.gov.uk/maff/archive/food/infsheet/1995/no53/53bee.htm (retrieved Mar14, 2013).

MONTENEGRO, M.I; QUEIROS, M.A. \& DASCHBACH, J.L. 1991. Microelectrodes: Theory and Applications, NATO ASI Series, Kluwer Academic Publishers.

MORGANO, M.A.; MARTINS, M.C.T.; RABONATO, L.C.; MILANI, R.F.; YOTSUYANAGI, K. \& RODRIGUEZAMAYA, D. B. 2012. A Comprehensive Investigation of the Mineral Composition of Brazilian Bee Pollen: Geographic and Seasonal Variations and Contribution to Human Diet.J. Braz. Chem. Soc., 23: 727-736. http://dx.doi.org/10.1590/S010350532012000400019

MORGANO, M.A.; MARTINS, M.C.T.; RABONATO, L.C.; MILANI, R.F.; YOTSUYANAGI, K. \& RODRIGUEZAMAYA, D. B. 2010. Inorganic Contaminants in Bee Pollen from Southeastern Brazil. J. Agric. Food Chem. 58:6876-6883. http://dx.doi.org/10.1021/jf100433p.

OGA, S.; CAMARGO, M. M. A. \& BATISTUZZO, J. A. O. 2008. Fundamentos de toxicologia. 3.ed. São Paulo: Atheneu, 690 p.

PEREIRA, L. L. 2010. Análise físico-química de amostras de méis de Apis mellifera e Meliponíneos. 84p. Dissertação (Mestrado em Entomologia) - Escola Superior de Agricultura "Luíz de Queiroz", Universidade de São Paulo. Piracicaba.

POHL, P.; SERGIEL, I. \& STECKA, H. 2009 'Determination and Fractionation of Metals in Honey'.Crit. Rev. Anal. Chem., 39:276-288. http://dx.doi.org/10.1080/10408340903001250

PORRINI, C.; SABATINI, A. G; GIROTTI, S.; GHINI, S.; MEDRZYCKI, P.; GRILLENZONI, F.; BORTOLOTTI, L.; GATTAVECCHIA, E. \& CELLI, G. 2003. Honey bees and bee products as monitors of the environmental contamination. Apiacta, 38: 63-70.

RAMOS, M. G. M. 2005 Determinação dos teores de metais pesados e plantas típicas dos mangues do Rio Cubatão, SP. 41p. Dissertação (Mestrado em Saúde Coletiva) - Universidade Católica de Santos, Programa de Mestrado em Saúde Coletiva. Santos, 2005.

RISSATO, S.R.; GALHIANE, M. S.; KNOLL, F.R.N.; ANDRADE, R. M. B. \& ALMEIDA, M. V. 2006. Método multirresíduo para monitoramento de contaminação ambiental de pesticidas na região de Bauru (SP) usando mel como bio-indicador. Quim. Nova, 29: 950-955. http://dx.doi.org/10.1590/S0100-40421999000300026. 
ROCHA, A.A.; PEREIRA, D.N. \& PADUA, H.B. 1985. Produtos de pesca e contaminantes químicos na água da represa Billings. Rev. SaúdePública São Paulo, 19: 401-410. http://dx.doi.org/10.1590/ S0034.

RODRIGUES, L.N.C. 1998. Analise de ceflacor em formulações farmacêuticas e urina humana através da polarografia de pulso diferencial e voltametria de redissolução catódica. Araraquara, 160p. Dissertação - Instituto de química de Araraquara. Universidade Estadual Paulista.

SALGADO, P. E. T. 2008. Metais em alimentos. In: OGA, S. (Ed.) Fundamentos de toxicologia. São Paulo: Atheneu. cap. 5.1, p.577-608.

SAS INSTITUTE. SAS/Stat 9.1.3 Service Pack 2. Cary, 2003.

SERRA-BONVEHÍ, J.S. \& ESCOLÀ JORDÀ, R. E. 1997. Nutrient Composition and Microbiological Quality of Honeybee-Collected Pollen in Spain. J. Agric. Food Chem, 45: 725-732. http://dx.doi. org/10.1021/jf960265q

SOMERVILLE, D.C. \& NICOL, H.I. 2002. Mineral content of honeybee-collected pollen from southern New South Wales. Aust J Exp Agric, 42:1131-1136. http://dx.doi.org/10.1071/ EA01086.
SOBUKOLA, O.P.; AWONORIN, S.O.; IDOWU, M.A. \& BAMIRO, F.O. 2008. Chemical and physical hazard profile of 'Robo' processing - a street vended melon snack. Int. J. Food Sci. Technol, 43:237-242. http://dx.doi.org/10.1111/j.1365-262 1.2006.01424

SKOOG, D. A. \& LEARY, J. L. 1992. Principles of instrumental analysis. Fourth Edition. Harcounnt Brave College Publishers. Forth Worth, 220p.

TADDIA, M.; MUSIANI, A. \& SCHIAVI, S. 2004. Determination of heavy metals in honey by zeeman electrothermal atomic absorption spectrometry. Ann.Chim. (Rome), 94 :107-111. http://dx.doi.org/10.1002/adic.200490001.

TONIETTO, A.E. \& GRASSI, M. T. 2012. Análise de Especiação de Cobre e Zinco empregando Voltametria de Redissolução Anódica com Pulso Diferencial. Quim. Nova, 35: 170-174. http://dx.doi. org/10.1590/S0100-40421999000300026.

WORD HEALTH ORGANIZATION (WHO). 2005. Mercury in drinking-water. Copenhagem. Disponível em: $<$ http://www.who. int/entity/water_sanitation_health/dwq/chemicals/mercuryfinal. pdf $>$. Acesso em: 12 dez. 2010 . 